\title{
Measuring and Comparing Party Ideology and Heterogeneity
}

\author{
Royce Carroll \\ University of Essex \\ r.carroll@essex.ac.uk \\ Hiroki Kubo \\ Osaka University \\ kubo@osipp.osaka-u.ac.jp
}

\begin{abstract}
Estimates of party ideological positions in Western Democracies yield useful party-level information, but lack the ability to provide insight into intraparty politics. In this paper, we generate comparable measures of latent individual policy positions from elite survey data which enable analysis of elite-level party ideology and heterogeneity. This approach has advantages over both expert surveys and approaches based on behavioral data, such as roll call voting and is directly relevant to the study of party cohesion. We generate a measure of elite positions for several European countries using a common space scaling approach and demonstrate its validity as a measure of party ideology. We then apply these data to determine the sources of party heterogeneity, focusing on the role of intraparty competition in electoral systems, nomination rules, and party goals. We find that policy-seeking parties and centralized party nomination rules reduce party heterogeneity. While intraparty competition has no effect, the presence of these electoral rules conditions the effect of district magnitude.
\end{abstract}




\section{Author Bios}

Royce Carroll is Reader in Comparative Politics at the University of Essex. He received his Ph.D. at the University of California at San Diego in 2007. His research focuses on democratic institutions and the role of representation in the policy-making process, particularly legislative politics and the politics of coalitions within and between political parties. His recent publications focus on political parties, the distribution of legislative power and on the spatial analysis of political choices in the measurement of preferences and ideology.

Hiroki Kubo is an Assistant Professor at Osaka School of International Public Policy, Osaka University. His research interests include comparative political institutions, political parties, electoral systems, and legislative studies in advanced democracies. 


\section{Introduction}

This paper proposes a measurement approach to politicians' policy positions from elite survey data with an application to the study of party heterogeneity. Estimating the policy positions of parties and politicians is key to understanding electoral competition, voterelite linkages, and coalition politics. Thus, methods have emerged focused on capturing the positions of parties as electoral entities. In particular, scholars have developed expert surveys (Laver and Hunt, 1992; Huber and Inglehart, 1995; Laver and Benoit, 2006; Bakker, Edwards, Jolly, Polk, Rovny and Steenbergen, 2014; Bakker et al., 2015) and analyses of party manifestos (Budge, Robertson and Hearl, 1987; Klingemann, Hofferbert and Budge, 1994; Budge, 2001; Klingemann et al., 2006; Volkens et al., 2013) to compare party ideological positions across time and across countries. The information derived from these approaches is aggregated by party and only loosely related to the preferences of actual party members. These measures allow no direct insight into the policy views among party members.

Yet, numerous studies have drawn attention to the importance of elite intraparty heterogeneity (Hazan, 2006, 2003; McGann, 2002; Özbudun, 1970; Giannetti and Benoit, 2008; Bowler et al., 1999; Owens, 2003), for example within coalition government (Laver and Shepsle, 1990; Bäck, 2008; Bäck, Debus and Müller, 2016; Kam et al., 2010; Giannetti and Benoit, 2008). The concept of party cohesion-preference similarity, distinct than behavioral unity (Depauw and Martin, 2009; Depauw, 1999; Carey, 2008), is directly important to the nature of democratic representation. If candidates represent a wide range of policy views, the concept of programmatic party representation is weakened (Pennings and Hazan, 2001; Giannetti and Benoit, 2008).

The literature has envisioned a number of reasons why party cohesion may vary. The incentives and ability for parties to attract more diverse candidate pools are said to vary with personal vote incentives, nomination procedures, and party goals. Yet, we lack ap- 
propriate tools to address such questions directly. Manifesto analysis and expert surveys are useful for capturing a party's overall position, but not the positions of party members. Meanwhile, behavioral measures focused on individuals, such as roll-call analysis, are not useful for uncovering individual policy preferences in many contexts, especially parliaments where party-line voting is nearly universal (Carroll and Poole, 2014; Spirling and McLean, 2007). While analysis of speech or co-sponsorship can provide useful information on the preferences of elected party members in some cases (Slapin and Proksch, 2008; Alemán et al., 2009; Bäck and Debus, 2016), such measures are not directly comparable across countries.

As an alternative, this study describes and compares the ideological positions and heterogeneity of parties by applying scaling techniques to issue questions in elite surveys. We use a scaling method designed precisely for this type of data, blackbox (Poole, 1998; Poole et al., 2015), to estimate individual ideological positions and then derive measures of overall party positions and party ideological homogeneity. Using this approach to capture elite ideology has several advantages. First, these estimated policy positions stem directly from individual candidate responses to policy questions, better reflecting policy preferences than behavioral measures. Second, these data are more comparable across contexts than other forms of data derived from individual politicians, enabling the cross-national analysis of party policy positions and intraparty politics. Third, these data reflect the preferences of the elites within parties, a distinct concept from voter or expert perceptions and campaign positioning. Such measures are important in order to directly assess questions such as party heterogeneity using the intraparty variance of our measure. While electoral systems and party organizational factors are often thought to affect intraparty elite ideological heterogeneity, this measure allows us to test these propositions.

This paper proceeds as follows. First, we present an overview of methods for measuring party preferences. Then we discuss scaling as a means to derive latent ideological mea- 
sures from the multiple issue scales in the European nations covered in the Comparative Candidate Survey (CCS) as a source of such data. We then present several descriptive illustrations of these measures and examine their face validity. In the final section, we apply this method of survey data analysis to explore the relationship between party ideological heterogeneity and variables related to electoral systems, party nomination practices and party types. We find that intraparty competition does not directly impact party ideological heterogeneity but mediates the effect of district magnitude in a manner consistent with the arguments of Carey and Shugart (1995): in countries without intraparty competition, lower district magnitudes increase heterogeneity; yet, the relationship is reversed when intraparty competition is present. Further, we find that candidate selection at the national level increases cohesion and that parties that prioritize their policy positions tend to recruit a more homogeneous pool of candidates.

\section{Background}

\subsection{Estimating party policy positions}

To date, most researchers measuring elite preferences in parliamentary regimes have focused on party-level measures such as manifesto analysis, voters' placements, and experts' judgments (Laver, 2014). Manifesto analysis focuses on parties' political messages to voters, estimating party policy positions from a content analysis of election manifestos (Budge, Robertson and Hearl, 1987; Budge, 2001; Klingemann, Hofferbert and Budge, 1994; Klingemann et al., 2006; Volkens et al., 2013). While this method has some weaknesses (Budge, 2000; Volkens, 2007; Mikhaylov, Laver and Benoit, 2012), it provides useful estimates of how parties present themselves in a cross-nationally comparable fashion (Budge and McDonald, 2007; König, Marbach and Osnabrügge, 2013). Voters' perceptions of left-right party positions from mass surveys can also be useful for understanding 
the ideology of parties (Dow, 2001; Blais and Bodet, 2006; Dalton, 2008; Ezrow, 2008; Dow, 2011) and in some cases it is possible to cross-nationally compare these ideological placements (Lo, Proksch and Gschwend, 2014; Saiegh, 2015). A third approach, expert surveys on party positions, also has provided highly useful data on the overall tendencies of parties (Laver and Hunt, 1992; Laver and Benoit, 2006; Benoit and Laver, 2007; Hooghe et al., 2010; Marks et al., 2007; Bakker, Jolly and Polk, 2012; Wiesehomeier and Benoit, 2009; Bakker et al., 2015) with cross-national comparability (Bakker, Edwards, Jolly, Polk, Rovny and Steenbergen, 2014; Bakker, Jolly, Polk and Poole, 2014).

However, while these approaches provide party-level estimates useful for many purposes, there are key limitations. First, they pertain to aspects of parties other than the preferences of their actual elite membership. Although politicians influence platforms and the party reputation perceived by experts and voters, these are also influenced by a large range of other factors. If we are interested in whether members of a party - that is, members seeking legislative office - differ from each other or those in other parties, these measures cannot directly capture this. Second, while each measure contains ways to account for uncertainty about party locations - e.g. using the variance across expert respondents (Rovny, 2012) or variance in manifesto scores (Jahn and Oberst, 2012), this is separate from the question of whether the party membership is ideologically cohesive. That is, these measures do not allow insight into the relationship between individual politicians and their party. Understanding internal ideological features of parties, such as heterogeneity, requires a measure focused directly on politicians themselves.

\subsection{Understanding intraparty politics using individual policy positions}

One common method to estimate individual legislators' policy positions is roll call analysis (Clinton, Jackman and Rivers, 2004; Poole, 2005), especially in the study of the US 
Congress (Poole and Rosenthal, 1997; Poole, 2005; Poole and Rosenthal, 2011) and other presidential democracies (Morgenstern, 2003; Desposato, 2005, 2006). Of course, roll call records are typically not useful for measuring individual preferences in parliamentary systems, where party discipline ensures high party unity in voting (Sieberer, 2006; Spirling and McLean, 2007). Moreover, substantial variation in the selectivity of votes (Carrubba et al., 2006; Carrubba, Gabel and Hug, 2008; Carey, 2008) adds further limits to the validity and comparability of these data as a measure of preferences. While the use of speech patterns in legislatures has considerable value for analyzing intraparty politics (Proksch and Slapin, 2014; Bäck and Debus, 2016), this comes without direct comparability across chambers.

We focus here on the value of elite surveys as an alternative source for analyzing party policy preferences and intraparty heterogeneity. Since elite surveys capture individual politicians' perceptions, researchers in American and comparative politics have sometimes used these to examine legislators' attitudes behind their behavior, often to contrast legislative voting behavior to measures derived from elite surveys (Ansolabehere, Snyder Jr and Stewart III, 2001; Kam, 2001; Coleman Battista and Richman, 2011).

In legislative studies, elite surveys are most commonly used for research related to roles and representation (Zittel and Gschwend, 2008; Kam et al., 2010; Scully, Hix and Farrell, 2012; André, Depauw and Martin, 2014; Deschouwer and Depauw, 2014; Bailer, 2014). However, little comparative work has exploited the potential of elite surveys as a source to obtain comparable latent ideological information. ${ }^{1}$ Estimating party and individual politicians' positions from elite surveys has several advantages. First, elite surveys allow insight into the internal politics of parties - how the ideological positions of party members relate to one another and to overall party positions. Second, unlike behavioral measures, the resulting ideological information stems directly from politicians' policy preferences, free from strategic considerations and party discipline. Further, estimating ideology as a

\footnotetext{
${ }^{1}$ Saiegh's work on Latin American countries $(2009 ; 2015)$ is an important exception.
} 
latent property based on issue perceptions allows greater comparability than questions of self-reported ideological labels due to the ability to link the latent ideological dimension across countries. As a result, applying this "joint scaling" method to issue scale questions can provide an elite ideological "common space" across several countries with which we can compare party positions and heterogeneity. ${ }^{2}$

\section{Survey data analysis for intraparty politics}

\subsection{Blackbox scaling}

We use a scaling technique to uncover the basic policy space contained within the issue scales of elite survey data (Poole, 1998; Saiegh, 2009; Poole et al., 2013; Armstrong et al., 2014; Poole et al., 2015). Blackbox scaling has in common with roll-call scaling analysis, such as those developed by Poole and Rosenthal (1997) and Clinton, Jackman and Rivers (2004), the aim to uncover latent dimensions of data. These methods improved on traditional multi-dimensional scaling by enabling a direct and precise estimation of 'ideal points' using an iterative process of maximizing the fit of binary choice models, rather than simply uncovering the main dimensions of a covariance matrix. Poole (1998) developed the blackbox scaling procedure specifically to estimate ideal points on the main latent dimensions of variance present in a series of issues scale questions (Armstrong et al., 2014; Poole et al., 2013, 2015). Furthermore, as the method is robust to the presence of missing data, data from common questions in multiple surveys can be used to generate a 'common space'. That is, by applying this method to the policy issue questions that are shared across the surveys, we can recover a common ideological space among the

\footnotetext{
${ }^{2}$ Of course, there still may exist Differential Item Functioning (DIF) effects even on the most straightforward of issue questions and even when aggregating across issues. This is impossible to address with any current data available. However, we believe these issues are mitigated by the tendency for elites from the European region to have a common understanding of basic issue concepts at hand. Certainly this problem should be less severe than the distortions we would expect from questions involving abstract concepts such as "left" and "right" labels.
} 
respondents, similar to .

Blackbox scaling takes as its input a matrix of issue scale data from surveys. We begin with a data matrix of survey data $x_{i j}$, where be the $i$ th individual respondent's $(i=1, \ldots$, $n$ ) reported policy position on the $j$ th issue $(j=1, \ldots, q)$ in each cell. Furthermore, let $X_{0}$ be the $n$ by $q$ matrix of survey data. This survey data matrix is decomposed to individual respondents' true coordinates $(\Psi)$ multiplied by weights that map the positions to the basic space $(W)$, a intercept term $(c)$, and an error term $\left(E_{0}\right)$ as follows:

$$
X_{0}=\left[\Psi W^{\prime}+J_{N} c^{\prime}\right]_{0}+E_{0}
$$

Let $\Psi_{i k}$ be the $i$ th individual's position on the $k$ th $\left.(k=1, \ldots, d)\right)$ basic dimension with the number of basic dimensions d less than the number of survey issues $q$. The coordinates of individual respondents are obtained by solving this equation. ${ }^{3}$

\subsection{The Comparative Candidates Survey (CCS)}

We use the Comparative Candidates Survey (CCS), which contains candidate surveys across Europe as our source to recover ideological information. ${ }^{4}$ This dataset is designed to analyze candidates running in a number of national parliamentary elections using a common format. Since our concern here is to determine comparable latent ideological dimensions, we are only able to make use of the 14 common survey questions on policy issues (Table 1) in 13 countries (Table 2).The CCS data set contains 17,922 respondents in 24 elections in 19 countries. Given our concerns for comparability here, we are only able to make use of 8,130 respondents in the following 13 election surveys: Australia 2007, Austria 2008, Belgium 2007, Denmark 2011, Finland 2011, Germany 2009, Greece

\footnotetext{
${ }^{3}$ It is also possible to generate standard errors for each individual ideal point using the parametric bootstrap, as described in Poole et al. (2015). Although we make use of the scores in the aggregate here, it is possible to test the differences between individual members using the uncertainty of the estimation.

${ }^{4}$ http://www.comparativecandidates.org/
} 
2007, Iceland 2009, Ireland 2007, Netherlands 2006, Norway 2009, Portugal 2011, Sweden

2010. In these 13 election surveys, the 14 policy questions can be jointly scaled to develop comparable measures cross-nationally. ${ }^{5}$

In this sample, the response rates of the candidate surveys range from $22.3 \%$ (Portugal in 2011) to $66.7 \%$ (Iceland in 2009). The resulting number of respondents is nevertheless at least 169 (Netherlands in 2006). A list of information about the surveys is provided in Table 2. ${ }^{6}$ Although we have taken measures to retain the most high quality data, ultimately the importance of the response rate in undermining the utility of the surveys depends on whether there is a significant distortion due to bias in the responses. In the following section we focus on establishing the face validity of the resulting data. ${ }^{7}$

We recover ideal points for 8,130 respondents in the 13 elections (country-years). In our scaling, the first dimension is correlated with the overall left-right (mostly economic) issues and the second dimension of the scaled data is driven mostly by certain moral issues. The eigenvalues of these data indicates the 1st dimension explains about 41.77 percent of the variation and the 2nd dimension explains only about 11.72 percent of the variation. In terms of the content of the two dimensions, the first dimension is most strongly correlated with attitudes toward income and wealth redistribution and military activity against terrorism. The first dimension is also driven somewhat by the questions on immigrants adjusting to local customs and stiffer sentences for criminals. Thus, the

\footnotetext{
${ }^{5}$ We cannot make use of 11 out of 24 CCS election surveys for several reasons. First, due to lacking most or all parts of these 14 comparable questions, we are unable to use the following 7 election surveys from the CCS: Australia 2010, Canada 2008, Estonia 2011, Finland 2007, Germany 2005, Hungary 2010, and Romania 2012. Second, Switzerland is not included to keep consistency in the parliamentary regime type for our comparison and because the extremely large number of candidates.

${ }^{6}$ We also exclude 2 election surveys (Czech Republic 2006 and Portugal 2009) because the respondent rates in the two election surveys are very low, below 20\%. The precise response rates in Belgium 2007 and Germany 2009 are not available. However, we were able to estimate an approximate response rate using the candidate totals from other survey years. For the survey in Belgium for 2010, the total candidates surveyed was 1,139 while Germany's 2005 survey indicates that the total was 2,346. These figures imply that the respondent rates Belgium in 2007 and Germany in 2009 are about 40\%, well above the $20 \%$ threshold. A further discussion of the response rates is in the appendix.

${ }^{7} \mathrm{An}$ additional discussion of response rates is located in the appendix. While we cannot definitively rule out bias within parties in terms of tendencies to respond, we do not find the response rates by party to be distributed in a manner that causes concern.
} 
common space here integrates a number of issues into a main underlying dimension. The second dimension is most correlated with the question of whether same-sex marriages should be prohibited. Correlations with each question are shown in Table 5 in the appendix. While we find some multidimensionality in the ideological common space among European politicians, the first dimension is dominant relative to the second and other dimensions, and the second dimension is not much greater than subsequent dimensions in its importance. We focus on the first dimension for the applications shown below. 
Table 1: Survey Items about Policy Questions in CCS

\begin{tabular}{ll}
\hline & Question \\
\hline $\mathrm{C} 2 \mathrm{a}$ & Immigrants should be required to adjust to the customs of [country]. \\
$\mathrm{C} 2 \mathrm{~b}$ & Politics should abstain from intervening in the economy. \\
$\mathrm{C} 2 \mathrm{c}$ & Stronger measures should be taken to protect the environment. \\
$\mathrm{C} 2 \mathrm{~d}$ & Same sex marriages should be prohibited by law. \\
$\mathrm{C} 2 \mathrm{e}$ & Women should be given preferential treatment when applying for jobs and promotions. \\
$\mathrm{C} 2 \mathrm{f}$ & People who break the law should be given stiffer sentences. \\
$\mathrm{C} 2 \mathrm{~g}$ & Providing a stable network of social security should be the prime goal of government. \\
$\mathrm{C} 2 \mathrm{~h}$ & Income and wealth should be redistributed towards ordinary people. \\
$\mathrm{C} 2 \mathrm{i}$ & Our democracy needs serious reform. \\
$\mathrm{C} 2 \mathrm{j}$ & Immigrants are good for [country's] economy. \\
$\mathrm{C} 2 \mathrm{k}$ & Women should be free to decide on matters of abortion. \\
$\mathrm{C} 2 \mathrm{l}$ & [Country] should provide military assistance to the "war on terror". \\
$\mathrm{C} 2 \mathrm{~m}$ & Torturing a prisoner is never justified even if it might prevent a terrorist attack. \\
$\mathrm{C} 2 \mathrm{n}$ & Globalisation should be promoted. \\
\hline
\end{tabular}

Table 2: Data Structure of the Comparative Candidates Survey (CCS)

\begin{tabular}{lrrrr}
\hline Country & Year & Total candidates & Respondents (rate) & \# Usable Observations \\
\hline Australia & 2007 & 950 & $472(49.7 \%)$ & 458 \\
Austria & 2008 & 4080 & $966(23.7 \%)$ & 954 \\
Belgium & 2007 & NA & 509 (approx. 40\%) & 505 \\
Denmark & 2011 & 784 & $375(47.8 \%)$ & 294 \\
Finland & 2011 & 2315 & $911(39.4 \%)$ & 902 \\
Germany & 2009 & $\mathrm{NA}$ & 789 (approx. $45 \%)$ & 777 \\
Greece & 2007 & 700 & $241(34.4 \%)$ & 196 \\
Iceland & 2009 & 756 & $504(66.7 \%)$ & 354 \\
Ireland & 2007 & 466 & $186(39.9 \%)$ & 182 \\
Netherlands & 2006 & 489 & $170(34.8 \%)$ & 169 \\
Norway & 2009 & 1972 & $1015(51.5 \%)$ & 1006 \\
Portugal & 2011 & 1150 & $257(22.3 \%)$ & 257 \\
Sweden & 2010 & 4056 & $1741(43.0 \%)$ & 1499 \\
\hline
\end{tabular}


Figure 1: Party Medians (Estimated 1D) by Country

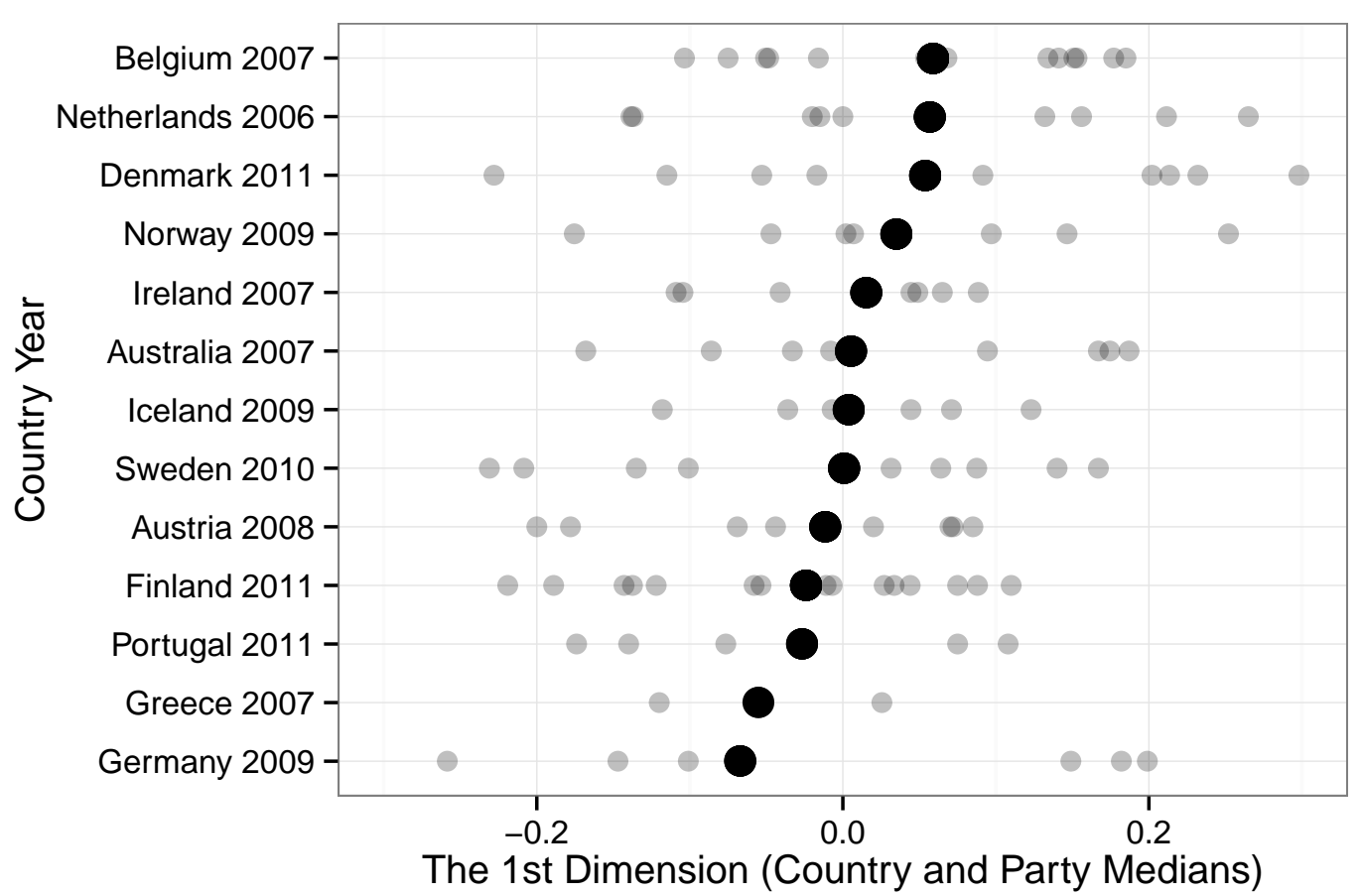

\subsection{Examining the data: party positions and ideological hetero- geneity}

To describe the data resulting from the scaling, we present several depictions of the estimates. For each party, we calculate the median value and standard deviation. ${ }^{8}$ Figure 1 shows the 105 party medians and the country median in the 13 election surveys. ${ }^{9}$ Some party systems in the Netherlands, Belgium and Denmark are rightward and other systems (Germany, Greece and Portugal) are leftward. Moreover, Figure 2 indicates the party heterogeneity of the 105 parties and the mean of their standard deviations.

Next we compare parties within and across groupings of "party families"(Von Beyme, 1985; Mair and Mudde, 1998). Members of party families have widely been compared us-

\footnotetext{
${ }^{8}$ While the total number of parties is 110 , we remove parties whose sample sizes are less than 5 , leaving 105 parties.

${ }^{9}$ Figure 5 in the appendix shows a scatter plot of the first two coordinates of scaled estimates from the 8,130 individual candidate respondents by country-year.
} 
Figure 2: Party SD (Estimated 1D) by Country

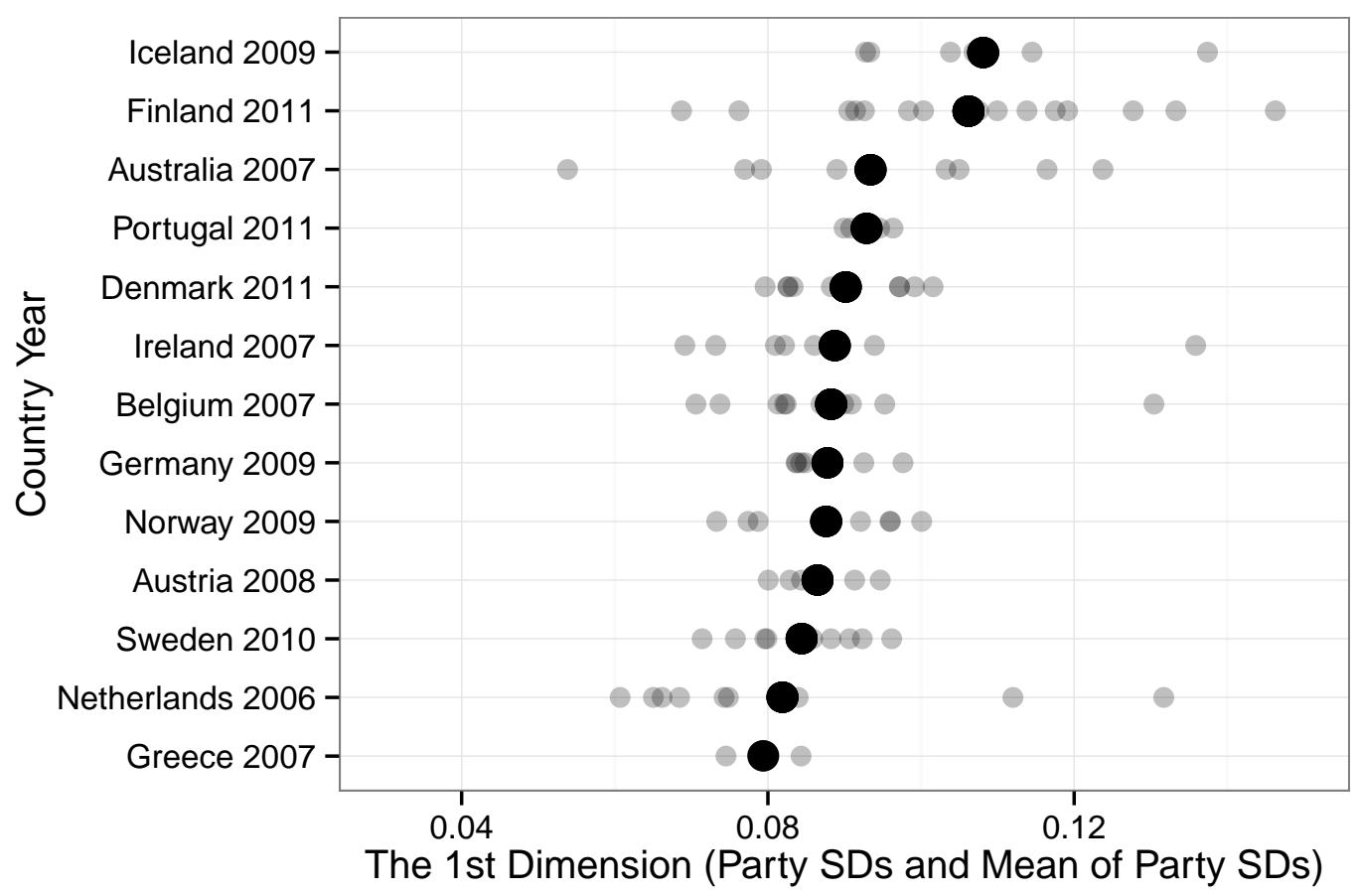

ing mass surveys, expert surveys and manifesto data (Camia and Caramani, 2012; Ennser, 2010). Ideological positions derived from issue scale data, which we present here, provides a direct measure of the views of the politicians making up these parties, rather than party campaign presentations or the perceptions of citizens or experts. Figure 3 shows the party positions of parties grouped by party family. Using the CHES categorization, we place parties into 7 groups. Note that liberal parties (followed by conservatives) tend to be an especially ideologically varied party family across countries while green parties (followed by far left and socialist parties) tend to be much more similar across countries. This is generally consistent with the expert-based findings of Ennser (2010). However, the elitebased measure presented here suggests more diversity across countries within the group of "right parties." 
Figure 3: Estimated Party Positions Grouped by Party Family

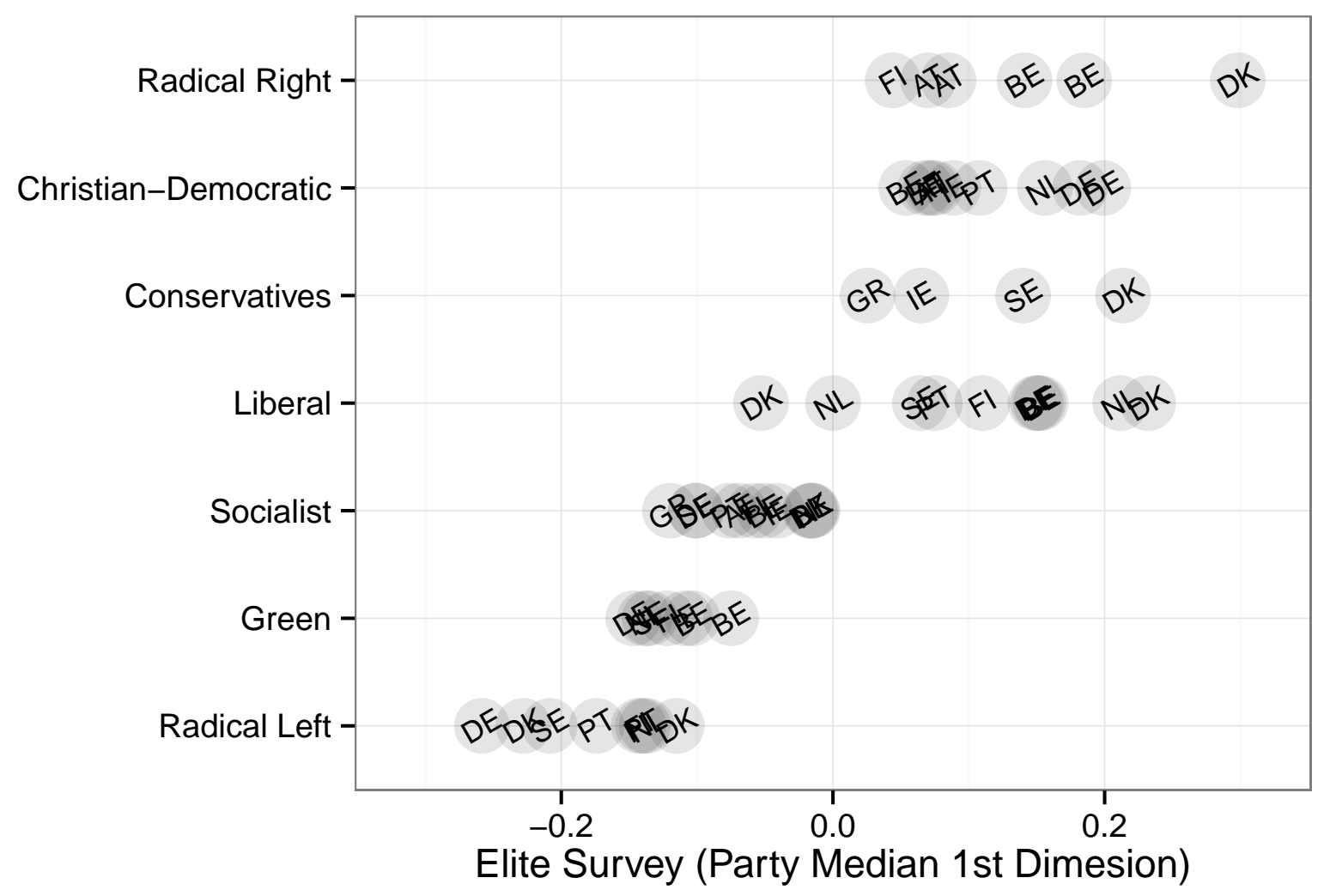




\section{Validity of the Estimates}

\subsection{Comparison with other measures}

We next examine the validity of party policy positions and heterogeneity by comparing with "left-right" information from three external sources: two expert surveys and measures derived from party manifestoes. Figure 4 displays the relationship between the party medians estimated from CCS and left-right party means from the Chapel Hill Expert Survey (CHES) (Bakker et al., 2015), the Democratic Accountability and Linkages Project (DALP) expert survey (Kitschelt and Kselman, 2013), and the Comparative Manifestos Project (CMP) (Lehmann et al. 2016). For the CHES, we use the values of party means for the "Left-Right General" score from the 2010 survey, the year closest to the elite survey data. Overall, the party medians in the elite survey and the party means of the expert surveys are strongly correlated at .87 and .89 each. The relationship with the CMP left-right scores is weaker at .69. A further analysis of the relationship between the estimates and the full set of CHES issue questions is discussed in the appendix in Table 4. 
Figure 4: The relationship between Estimates and Three Expert Surveys (CHES, DALP, CMP)
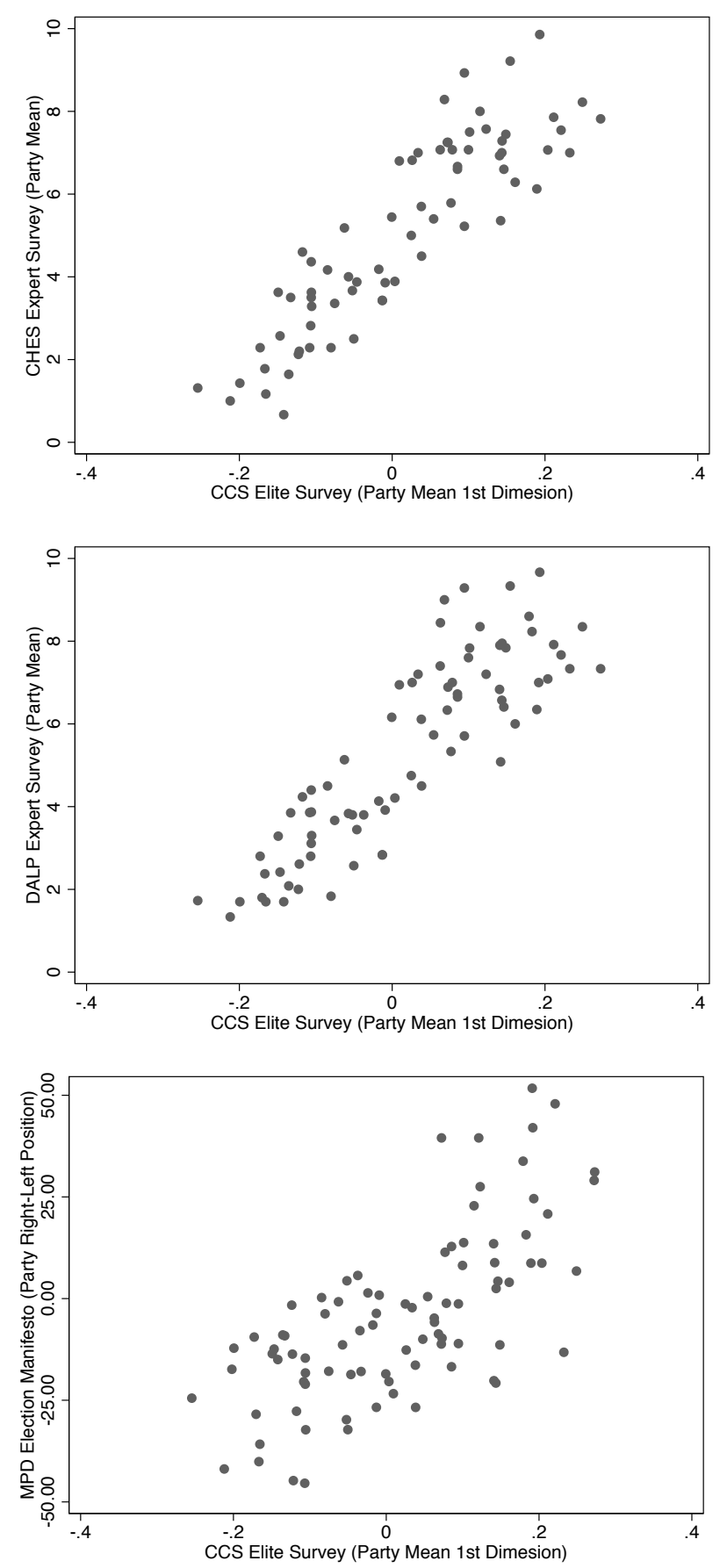


\section{Analysis: Determinants of ideological heterogene- ity within parties}

\subsection{Dependent variable}

As explained above, an important function of measuring preference heterogeneity is to understand the correlates of heterogenous preferences, by contrast to heterogeneous behavior (Hazan, 2006, 2013; Özbudun, 1970). The extant literature on the determinants of party cohesion highlights three major elements relevant to cross national analysis. One of these is the incentive electoral institutions provide for members of parties to differentiate from their party and from one another. Second, parties may be able to more easily recruit for cohesion because of better control over nomination procedures. Finally, regardless of the control national parties have over nominations, they may vary in the degree to which cohesion is valued, as parties prioritizing seeking office over policy may compromise their policy cohesion.

One of the first major works highlighting the importance of the electoral system, Katz (1986), famously noted that "intraparty preference voting creates a powerful incentive to disunity" (p.101) .Carey and Shugart (1995) specified in more detail how intraparty competition and district magnitude combine to encourage politicians to pursue a personal vote. While the personal vote literature has long focused on non-ideological implications such as constituency service (Cain, Ferejohn and Fiorina, 1987; Heitshusen, Young and Wood, 2005) and particularism (Ames, 1995; Hallerberg and Marier, 2004), this literature has also evolved to include the idea that personal vote incentives would reduce policy cohesion more broadly among parties. Kitschelt and Smyth (2002), for instance, argue that "party cohesiveness is least likely in multi-member districts that use preferential votes to choose individual candidates on party lists" (p.1234). Scheiner (2006) suggests that "where institutions encourage personalistic competition, coherent and complex pro- 
grammatic parties are slow to develop because of the differing, personal agendas of their members" (p.67). Most empirical literature looks at behavioral phenomena such as legislative voting unity, which is in large part driven by party discipline, rather than party heterogeneity per se (Carey, 2008; Sieberer, 2006; Depauw and Martin, 2009). However much of the work in this vein implies that preference cohesion would be reduced by a personal-vote oriented electoral system, due to encouraging a more diverse party. Still, evidence with regard to the effects of personal vote incentives on cohesion has been inconclusive at best, particularly given the use of indirect behavioral measures of party unity, such as roll call voting (Owens, 2003) which results from many different sources (Carey, 2008). Here, we are able to test whether party heterogeneity is related to electoral systems encouraging intraparty competition - the ability to vote for candidates of the same party - and district magnitude. We thus hypothesize that:

\section{H1. Intraparty competition increases party heterogeneity}

An important caveat here is that, as Carey and Shugart (1995) explain, district magnitude (the number of seats in districts) also influences personal vote incentives. Specifically, higher district magnitudes should increase personalization when intraparty competition is present and decrease personalization when it is not present. Thus, while in general we might have imagined that smaller district magnitudes to increase heterogeneity, this argument suggests we should expect this only in cases without intraparty competition. Meanwhile, district magnitude may otherwise decrease heterogeneity.

H2a. District magnitude increases party heterogeneity when intraparty competition is present

H2b. District magnitude decreases party heterogeneity when intraparty competition is not present

Electoral systems can only play a limited role in generating party heterogeneity because party nomination practices can produce parties that have recruited cohesively, regardless of specific electoral rules (Bowler et al., 1999). Since the work of Schattschneider (1942), 
scholars have noted the importance of party control over the selection and nomination of candidates for office where centralized control is expected to enable parties to recruit to ensure a cohesive membership (Gallagher and Marsh, 1987; Katz and Mair, 1992; Hazan, 2003; Hazan and Rahat, 2010; Cross and Katz, 2013; Rahat and Hazan, 2001). As Pennings and Hazan (2001) note, "the cohesion of the party is closely related to the locus of selection" (p. 271). Carey (2008) notes that centralized control over nominations allows party leaders to "screen potential candidates for ideological compatibility with national party priorities, and so to foster cohesiveness among those ultimately elected" (p. 127). With a centralized process, parties can ensure that members adhere to the policy positions of the party before deciding on a nomination (Andeweg and Thomassen, 2010; Faas, 2003; Hix, 2004). Without centralized control over nominations, members with preferences diverging from the national leadership may become candidates, leading to greater diversity in views among candidates (Rahat and Sheafer, 2007; Kristjánsson, 1998)

\section{H3. Centralized candidate nomination process will reduce party heterogeneity}

A third key factor that would regulate whether parties would attract and recruit a cohesive membership are the goals of the party. Kitschelt (2000) notes that many parties will simply not be programmatic in their goals. Although few parties in this sample engage in linkages that could be called clientelistic, certainly many are more office seeking than policy-seeking. Strøm (1990) notes that parties may greatly sacrifice coherent policy goals in order to seek office, which creates incentives to recruit heterogeneous members and encourages a broad array of members to join (Hansen and Rasmussen, 2013). Meanwhile, more policy-seeking parties are relatively more likely to emphasize a consistent policy position among members in order to facilitate programmatic goals (Pedersen, 2012). Parties that emphasize maintaining clear policy positions will enhance ideological homogeneity through self-selection (Andeweg and Thomassen, 2010). In turn, parties with greater emphasis on ideological positioning in their goals will be less likely to attract candidates with divergent preferences. 
H4. Parties emphasizing policy positions will be associated with less party heterogeneity

In addition, extant literature suggests we should control for two basic features of parties, size and ideology. A larger party is more likely to be heterogeneous because, (Sieberer 2006:154), "especially large parties representing more than one social group have incentives to diversify their offer, thus accepting a certain degree of preference heterogeneity among candidates." Meanwhile, it is often thought that parties on a certain side of the political spectrum may be more or less heterogeneous, with left-wing parties being particularly associated with homogeneity (e.g. Ennser 2010)

\subsection{Measures}

To operationalize party heterogeneity — policy preference diversity among party membershipwe simply calculate the standard deviation of the main dimension of the scaled elite survey data.

To capture intraparty competition we create a dummy variable assigning 1 to the four countries in which the ability of individual candidates to win seats can be influenced by their personal votes: Greece, Finland, Ireland, and Denmark. ${ }^{10}$

We also consider the effect of district magnitude, measured as the log-transformed median value for each country, which is expected to increase personalization on average as the number of seats in districts decreases when intraparty competition is not present and Increase otherwise. This measure comes from Carey and Hix (2011).

To measure party nomination processes and the types of competition the party engages in we make use of the Democratic Accountability and Linkages Project (DALP) 2008-9 Dataset $^{11}$. We match the parties in the CCS data (above-mentioned 105 parties in 13

\footnotetext{
${ }^{10}$ These cases make use of either open-list PR or STV. Our coding of the presence of intraparty competition for this sample is based on Katz (1986). This coding is also consistent with the recent work of Valdini $(2006,2013)$ and Ortega Villodes (2006).

${ }^{11} \mathrm{http} / / /$ sites.duke.edu/democracylinkage/
} 
country years) to the parties in DALP. ${ }^{12}$ To measure the locus of nomination power we used a party level variable National Candidate Selection Power which captures the nomination influence of national party leaders relative to regional and local nomination influence.

We also make use of DALP to capture the degree of policy orientation of party appeals to voters. The question Policy Positions captures experts' perceptions on the degree to which parties focus on their policy positions. ${ }^{13}$

Finally, we also include measures of party size (Party Vote Share) and expert survey locations of left-right ideology from the DALP data set.

\section{$5.3 \quad$ Results}

We make use of a multi-level linear regression including country-year random effects. Table 3 shows the results of this analysis in model 1. First, we find no overall effect of intraparty competition in the full sample. However, we find several effects of party organizational factors here. First, National Candidate Selection is associated with higher party ideological heterogeneity. Second, we find that Party Policy Emphasis is negatively related with party ideological heterogeneity, as we expect. Parties known for programmatic messaging tend to be less ideologically heterogeneous - that is, more cohesive. No effects are found for either left-right position or party size.

In order to investigate the effects of district magnitude more closely, in models 2 and 3 , we examine a subsample of countries with intraparty competition encouraged by electoral rules and a sample of those without. While these subsamples are small, they do allow us to determine if there is any tendency for the effect of district magnitude to exist. Here, we

\footnotetext{
${ }^{12} \mathrm{As}$ we discuses above, we estimate the values of party heterogeneity of 110 parties in 13 country years. Since some parties and data in Iceland are not available in DALP, 78 parties in 12 country years are matched. Thus, we analyze these 78 observations in the following.

13 "Please indicate the extent to which parties seek to mobilize electoral support by emphasizing the attractiveness of the party's positions on policy issues."
} 
find that indeed the effect of district magnitude is present and negative when no intraparty competition exists. However, it is positive (encouraging heterogeneity) when intraparty competition is present. Thus while we find no evidence of a difference in heterogeneity on average due to intraparty competition, we find some evidence for the mediating effect of such electoral systems on district magnitude. ${ }^{14}$ We also note that the findings regarding national candidate selection and party policy emphasis Are present in the sample without intraparty competition. Moreover, there is an effect of left-right position within this subsample-with 'rightist' parties tending to be more cohesive.

\footnotetext{
${ }^{14}$ The effect of district magnitude with and without intraparty competition is also statistically significant when tested as an interaction term
} 
Table 3: Determinants of Party Heterogeneity

(1)

(3)

All Cases No Intraparty Intraparty Competition Competition

\begin{tabular}{lccc}
\hline & & & \\
Log District Magnitude & -.123 & $-.262^{*}$ & $1.155^{* * *}$ \\
& $(.135)$ & $(.103)$ & $(.338)$ \\
Intraparty Competition & -.247 & & \\
& $(.315)$ & & \\
National Candidate Selection & $-.864^{* *}$ & $-.676^{*}$ & $-1.575^{+}$ \\
& $(.318)$ & $(.296)$ & $(.892)$ \\
Party Policy Emphasis & $-1.216^{* *}$ & $-1.302^{* *}$ & -.763 \\
& $(.397)$ & $(.406)$ & $(.795)$ \\
Left-Right Expert Position & -.041 & $-.113^{*}$ & .100 \\
& $(.047)$ & $(.050)$ & $(.088)$ \\
Party Vote Share & -.013 & $-.017^{+}$ & .013 \\
& $(.010)$ & $(.010)$ & $(.019)$ \\
Constant & $14.096^{* * *}$ & $15.082^{* * *}$ & $8.528^{* *}$ \\
& $(1.650)$ & $(1.675)$ & $(3.302)$ \\
Observations & 78 & 55 & 23 \\
$\log ($ likelihood) & -105.731 & -66.683 & -28.143 \\
\hline \hline
\end{tabular}

Standard errors in parentheses

${ }^{+} p<0.10,{ }^{*} p<0.05,{ }^{* *} p<0.01,{ }^{* * *} p<0.001$ 


\section{Discussion}

This paper examines how we can measure and compare party elite ideological positions and heterogeneity using the latent information extracted by joint scaling issue questions in elite surveys. We propose a method to measure a dimension of ideological information useful for analyzing party politics, yet not accounted for in existing measures of party positions. This method focuses on the information derived from surveys of party candidates, as opposed to voter perceptions, political communications or the general reputation in the eyes of experts. Second, while the most commonly used methods provide only estimates party overall positions, this method accounts for the internal variance of the positions of elites within parties, a source of great interest in comparative politics. Using data from Europe, we show that the values of party median positions derived from scaling elite survey questions provide meaningful information and are comparable to those derived from elite surveys and party manifestoes, which demonstrates the face validity of this measure.

To demonstrate the utility of these data, we examine the determinants of party heterogeneity using the intraparty variance of our measure. In this analysis we test whether electoral systems and party organizational factors affect candidate ideological heterogeneity. First, we find that merely having an electoral system that encourages intraparty competition does not have an impact on party ideological heterogeneity. This suggests that findings related to party unity are probably due to the effects of intraparty competition on how party discipline is enforced, rather than the diversity of parties - at least in the parliamentary regimes examined here. However, we also find that district magnitude correlates with heterogeneity in a manner consistent with the arguments of Carey and Shugart (1995): in countries without intraparty competition, lower district magnitudes increase heterogeneity, as we would expect due to the localizing impact of smaller districts. In countries with intraparty competition, meanwhile, the relationship is positive: 
larger districts produce more heterogeneity. In addition, we find that parties that control their candidate selection mechanisms primarily at the national level tend to produce less heterogeneous parties. This suggests that local influence in the nomination process indeed increases the tendency for more diverse preferences and parties. Finally, parties that prioritize their policy positions tend to recruit a more homogeneous pool of candidates. We interpret this finding to suggest that more office seeking parties, who are not known for emphasizing policy positions, encourage a diverse set of members to join the party.

We suggest that using the latent positions derived from elite surveys is a promising approach to measuring party positions and capturing intraparty politics. Subject to the limitation that only a one year of information is currently available for each country, future work should consider using such estimates as potentially useful measures of the preferences of parties at the elite level and their heterogeneity. 


\section{References}

Alemán, Eduardo, Ernesto Calvo, Mark P Jones and Noah Kaplan. 2009. "Comparing Cosponsorship and Roll-Call Ideal Points." Legislative Studies Quarterly 34(1):87-116.

Ames, Barry. 1995. "Electoral Strategy under Open-List Proportional Representation." American Journal of Political Science 39(2):406-433. ArticleType: research-article / Full publication date: May, 1995 / Copyright (c) 1995 Midwest Political Science Association.

Andeweg, Rudy B and Jacques Thomassen. 2010. "Pathways to party unity: Sanctions, loyalty, homogeneity and division of labour in the Dutch parliament." Party Politics p. 1354068810377188.

André, Audrey, Sam Depauw and Shane Martin. 2014. "Electoral Systems and Legislators' Constituency Effort The Mediating Effect of Electoral Vulnerability." Comparative Political Studies p. 0010414014545512.

Ansolabehere, Stephen, James M Snyder Jr and Charles Stewart III. 2001. "The effects of party and preferences on congressional roll-call voting." Legislative Studies Quarterly pp. $533-572$.

Armstrong, David A, Ryan Bakker, Royce Carroll, Christopher Hare, Keith T Poole, Howard Rosenthal et al. 2014. Analyzing Spatial Models of Choice and Judgment with R. CRC Press.

Bäck, Hanna. 2008. "Intra-party politics and coalition formation: Evidence from Swedish local government." Party Politics 14(1):71-89.

Bäck, Hanna and Marc Debus. 2016. Political Parties, Parliaments and Legislative Speechmaking. Springer.

Bäck, Hanna, Marc Debus and Wolfgang C. Müller. 2016. "Intra-party diversity and ministerial selection in coalition governments." Public Choice 166:355-378.

Bailer, Stefanie. 2014. "Interviews and Surveys in Legislative Research." The Oxford Handbook of Legislative Studies p. 167.

Bakker, Ryan, Catherine De Vries, Erica Edwards, Liesbet Hooghe, Seth Jolly, Gary Marks, Jonathan Polk, Jan Rovny, Marco Steenbergen and Milada Anna Vachudova. 2015. "Measuring party positions in Europe The Chapel Hill expert survey trend file, 1999-2010." Party Politics 21(1):143-152.

Bakker, Ryan, Erica Edwards, Seth Jolly, Jonathan Polk, Jan Rovny and Marco Steenbergen. 2014. "Anchoring the experts: Using vignettes to compare party ideology across countries." Research 65 Politics 1(3):2053168014553502. 
Bakker, Ryan, Seth Jolly and Jonathan Polk. 2012. "Complexity in the European party space: Exploring dimensionality with experts." European Union Politics 13(2):219-245.

Bakker, Ryan, Seth Jolly, Jonathan Polk and Keith Poole. 2014. "The European Common Space: Extending the Use of Anchoring Vignettes." The Journal of Politics 76(04):1089-1101.

Benoit, Kenneth and Michael Laver. 2007. "Estimating party policy positions: Comparing expert surveys and hand-coded content analysis." Electoral Studies 26(1):90-107.

Blais, André and Marc André Bodet. 2006. "Does proportional representation foster closer congruence between citizens and policy makers?" Comparative Political Studies 39(10):1243-1262.

Bowler, Shaun, David M Farrell, Richard S Katz et al. 1999. Party discipline and parliamentary government. The Ohio State University Press.

Budge, Ian. 2000. "Expert judgements of party policy positions: Uses and limitations in political research." European Journal of Political Research 37(1):103-113.

Budge, Ian. 2001. Mapping policy preferences: estimates for parties, electors, and governments, 1945-1998. Vol. 1 Oxford University Press.

Budge, Ian, David Robertson and Derek Hearl. 1987. Ideology, strategy and party change: spatial analyses of post-war election programmes in 19 democracies. Cambridge University Press.

Budge, Ian and Michael D McDonald. 2007. "Election and party system effects on policy representation: Bringing time into a comparative perspective." Electoral Studies 26(1):168-179.

Cain, Bruce E, John A Ferejohn and Morris P Fiorina. 1987. "The personal vote: Constituency service and electoral independence.".

Camia, Valeria and Daniele Caramani. 2012. "Family meetings: Ideological convergence within party families across Europe, 1945-2009." Comparative European Politics 10(1):48-85.

Carey, John M. 2008. Legislative voting and accountability. Cambridge University Press.

Carey, John M and Matthew Soberg Shugart. 1995. "Incentives to cultivate a personal vote: a rank ordering of electoral formulas." Electoral studies 14(4):417-439.

Carey, John M. and Simon Hix. 2011. "The Electoral Sweet Spot: Low-Magnitude Proportional Electoral Systems." American Journal of Political Science 55(2):383-397.

Carroll, Royce and Keith Poole. 2014. "Roll call analysis and the study of legislatures." The Oxford handbook of legislative studies pp. 103-124. 
Carrubba, Clifford J, Matthew Gabel, Lacey Murrah, Ryan Clough, Elizabeth Montgomery and Rebecca Schambach. 2006. "Off the record: unrecorded legislative votes, selection bias and roll-call vote analysis." British Journal of Political Science 36(04):691704 .

Carrubba, Clifford, Matthew Gabel and Simon Hug. 2008. "Legislative voting behavior, seen and unseen: A theory of roll-call vote selection." Legislative Studies Quarterly $33(4): 543-572$.

Clinton, Joshua, Simon Jackman and Douglas Rivers. 2004. "The statistical analysis of roll call data." American Political Science Review 98(02):355-370.

Coleman Battista, James and Jesse T Richman. 2011. "Party pressure in the US state legislatures." Legislative Studies Quarterly 36(3):397-422.

Cross, William P and Richard S Katz. 2013. The challenges of intra-party democracy. Oxford University Press.

Dalton, Russell J. 2008. "The quantity and the quality of party systems party system polarization, its measurement, and its consequences." Comparative Political Studies 41(7):899-920.

Depauw, Sam. 1999. "Parliamentary Party Cohesion and the Searcity of Sanctions in the Belgian Chamber of Representatives." Res Publica: Tijdschrift voor Politologie 1:15-39.

Depauw, Sam and Shane Martin. 2009. "Legislative party discipline and cohesion in comparative perspective." Intra-party politics and coalition governments pp. 103-120.

Deschouwer, Kris and Sam Depauw. 2014. Representing the people: a survey among members of statewide and substate parliaments. OUP Oxford.

Desposato, Scott W. 2005. "Correcting for small group inflation of roll-call cohesion scores." British Journal of Political Science 35(4):731.

Desposato, Scott W. 2006. "The impact of electoral rules on legislative parties: Lessons from the Brazilian Senate and Chamber of Deputies." Journal of Politics 68(4):10181030 .

Dow, Jay K. 2001. "A comparative spatial analysis of majoritarian and proportional elections." Electoral Studies 20(1):109-125.

Dow, Jay K. 2011. "Party-system extremism in majoritarian and proportional electoral systems." British Journal of Political Science 41(02):341-361.

Ennser, Laurenz. 2010. "The homogeneity of West European party families: The radical right in comparative perspective." Party Politics p. 1354068810382936. 
Ezrow, Lawrence. 2008. "Parties' policy programmes and the dog that didn't bark: No evidence that proportional systems promote extreme party positioning." British Journal of Political Science 38(3):479.

Faas, Thorsten. 2003. "To defect or not to defect? National, institutional and party group pressures on MEPs and their consequences for party group cohesion in the European Parliament." European Journal of Political Research 42(6):841-866.

Gallagher, Michael and Michael Marsh. 1987. Candidate selection in comparative perspective. Sage Newbury Park, CA.

Giannetti, Daniela and Kenneth Benoit. 2008. Intra-party politics and coalition governments. Routledge.

Hallerberg, Mark and Patrik Marier. 2004. "Executive Authority, the Personal Vote, and Budget Discipline in Latin American and Caribbean Countries." American Journal of Political Science 48(3):571-587. ArticleType: primary_article / Full publication date: Jul., 2004 / Copyright (c) 2004 Midwest Political Science Association.

Hansen, Martin Ejnar and Niels Erik Kaaber Rasmussen. 2013. "Does Running for the Same Party Imply Similar Policy Preferences? Evidence from Voting Advice Applications." Representation 49(2):189-205.

Hazan, Reuven Y. 2003. "Introduction: Does cohesion equal discipline? towards a conceptual delineation." The Journal of Legislative Studies 9(4):1-11.

Hazan, Reuven Y. 2006. Cohesion and discipline in legislatures. Routledge.

Hazan, Reuven Y. 2013. Cohesion and discipline in legislatures. Routledge.

Hazan, Reuven Y and Gideon Rahat. 2010. Democracy within parties: candidate selection methods and their political consequences. Oxford University Press.

Heitshusen, Valerie, Garry Young and David M. Wood. 2005. "Electoral Context and MP Constituency Focus in Australia, Canada, Ireland, New Zealand, and the United Kingdom." American Journal of Political Science 49(1):32-45.

Hix, Simon. 2004. "Electoral institutions and legislative behavior: Explaining voting defection in the European Parliament." World politics 56(02):194-223.

Hooghe, Liesbet, Ryan Bakker, Anna Brigevich, Catherine De Vries, Erica Edwards, Gary Marks, Jan Rovny, Marco Steenbergen and Milada Vachudova. 2010. "Reliability and validity of the 2002 and 2006 Chapel Hill expert surveys on party positioning." European Journal of Political Research 49(5):687-703.

Huber, John and Ronald Inglehart. 1995. "Expert interpretations of party space and party locations in 42 societies." Party politics 1(1):73-111. 
Jahn, Detlef and Christoph Oberst. 2012. "Ideological Party Cohesion in Macrocomparative Politics: The Nordic Social Democratic Parties from a Comparative Perspective." Scandinavian Political Studies 35(3):222-245.

Kam, Christopher. 2001. "Do ideological preferences explain parliamentary behaviour? Evidence from Great Britain and Canada." Journal of Legislative Studies 7(4):89-126.

Kam, Christopher, William T Bianco, Itai Sened and Regina Smyth. 2010. "Ministerial selection and intraparty organization in the contemporary British parliament." American Political Science Review 104(2):289-306.

Katz, Richard. 1986. Intraparty preference voting. In Electoral laws and their political consequences. Agathon Press New York pp. 85-103.

Katz, Richard S. and Peter Mair. 1992. Party organization: A data handbook. London: Sage.

Kitschelt, Herbert. 2000. "Linkages between citizens and politicians in democratic polities." Comparative political studies 33(6-7):845-879.

Kitschelt, Herbert and Daniel M Kselman. 2013. "Economic development, democratic experience, and political parties' linkage strategies." Comparative political studies 46(11):1453-1484.

Kitschelt, Herbert and Regina Smyth. 2002. "Programmatic Party Cohesion in Emerging Postcommunist Democracies Russia in Comparative Context." Comparative Political Studies 35(10):1228-1256.

Klingemann, Hans-Dieter, Andrea Volkens, Judith Bara, Ian Budge, Michael D McDonald et al. 2006. Mapping policy preferences II: estimates for parties, electors, and governments in Eastern Europe, European Union, and OECD 1990-2003. Oxford University Press Oxford.

Klingemann, Hans-Dieter, Richard I Hofferbert and Ian Budge. 1994. Parties, policies, and democracy. Westview Press.

König, Thomas, Moritz Marbach and Moritz Osnabrügge. 2013. "Estimating Party Positions across Countries and Time-A Dynamic Latent Variable Model for Manifesto Data." Political Analysis 21(4):468-491.

Kristjánsson, Svanur. 1998. "Electoral politics and governance: Transformation of the party system in Iceland, 1970-96." Comparing party system change. London: Routledge pp. 167-182.

Laver, Michael. 2014. "Measuring policy positions in political space." Annual Review of Political Science 17(1). 
Laver, Michael and Kenneth A Shepsle. 1990. "Government coalitions and intraparty politics." British Journal of Political Science 20(04):489-507.

Laver, Michael and Kenneth Benoit. 2006. "Party Policy in Modern Democracies." London (Internet Final Version 28.11.

Laver, Michael and W Ben Hunt. 1992. Policy and party competition. Routledge.

Lo, James, Sven-Oliver Proksch and Thomas Gschwend. 2014. "A common left-right scale for voters and parties in Europe." Political Analysis 22(2):205-223.

Mair, Peter and Cas Mudde. 1998. "The party family and its study." Annual Review of Political Science 1(1):211-229.

Marks, Gary, Liesbet Hooghe, Marco R Steenbergen and Ryan Bakker. 2007. "Crossvalidating data on party positioning on European integration." Electoral Studies 26(1):2338 .

McGann, Anthony J. 2002. "The advantages of ideological cohesion a model of constituency representation and electoral competition in multi-party democracies." Journal of Theoretical Politics 14(1):37-70.

Mikhaylov, Slava, Michael Laver and Kenneth R Benoit. 2012. "Coder reliability and misclassification in the human coding of party manifestos." Political Analysis 20(1):7891.

Morgenstern, Scott. 2003. Patterns of legislative politics: Roll-call voting in Latin America and the United States. Cambridge University Press.

Ortega Villodes, Carmen. 2006. Preference voting systems and their impact on the personalisation of politics. In Comparative studies of electoral systems meeting (CSES), Sevilla, Spain.

Owens, John E. 2003. "Part 1: Cohesion: Explaining party cohesion and discipline in democratic legislatures: Purposiveness and contexts." The Journal of Legislative Studies 9(4):12-40.

Özbudun, Ergun. 1970. Party cohesion in Western democracies: A causal analysis. Sage.

Pedersen, Helene Helboe. 2012. "Policy-seeking parties in multiparty systems: Influence or purity?" Party Politics 18(3):297-314.

Pennings, Paul and Reuven Y. Hazan. 2001. "Democratizing candidate selection: causes and consequences." Party Politics 7(3):267-275.

Poole, Keith, Howard Rosenthal, James Lo, Royce Carroll and Maintainer James Lo. 2013. "Package 'basicspace'.". 
Poole, Keith, Jeffrey Lewis, Howard Rosenthal, James Lo and Royce Carroll. 2015. "Recovering a Basic Space from Issue Scales in R." Journal of Statistical Software (forthcoming).

Poole, Keith T. 1998. "Recovering a basic space from a set of issue scales." American Journal of Political Science pp. 954-993.

Poole, Keith T. 2005. Spatial models of parliamentary voting. Cambridge University Press.

Poole, Keith T and Howard L Rosenthal. 2011. Ideology and congress. Vol. 1 Transaction Publishers.

Poole, Keith T and Howard Rosenthal. 1997. Congress: A political-economic history of roll call voting. Oxford University Press.

Proksch, Sven-Oliver and Jonathan B Slapin. 2014. The Politics of Parliamentary Debate. Cambridge University Press.

Rahat, Gideon and Reuven Y Hazan. 2001. "Candidate selection methods an analytical framework." Party Politics 7(3):297-322.

Rahat, Gideon and Tamir Sheafer. 2007. "The personalization (s) of politics: Israel, 1949-2003." Political Communication 24(1):65-80.

Rovny, Jan. 2012. "Who emphasizes and who blurs? Party strategies in multidimensional competition." European Union Politics 13(2):269-292.

Saiegh, Sebastian M. 2009. "Recovering a basic space from elite surveys: Evidence from Latin America." Legislative Studies Quarterly 34(1):117-145.

Saiegh, Sebastián M. 2015. "Using Joint Scaling Methods to Study Ideology and Representation: Evidence from Latin America." Political Analysis p. mpv008.

Schattschneider, Elmer Eric. 1942. Party Government: American Government in Action. Transaction Publishers.

Scheiner, Ethan. 2006. Democracy without competition in Japan: Opposition failure in a one-party dominant state. Cambridge University Press.

Scully, Roger, Simon Hix and David M Farrell. 2012. "National or European Parliamentarians? Evidence from a New Survey of the Members of the European Parliament*." JCMS: Journal of Common Market Studies 50(4):670-683.

Sieberer, Ulrich. 2006. "Party unity in parliamentary democracies: A comparative analysis." The Journal of Legislative Studies 12(2):150-178.

Slapin, Jonathan B and Sven-Oliver Proksch. 2008. "A scaling model for estimating timeseries party positions from texts." American Journal of Political Science 52(3):705-722. 
Spirling, Arthur and Iain McLean. 2007. "UK OC OK? Interpreting optimal classification scores for the UK House of Commons." Political Analysis 15(1):85-96.

Strøm, Kaare. 1990. "A behavioral theory of competitive political parties." American Journal of Political Science pp. 565-598.

Valdini, Melody Ellis. 2006. Electoral institutions and information shortcuts: the effect of decisive intraparty competition on the behavior of voters and party elites. ProQuest.

Valdini, Melody Ellis. 2013. "Electoral Institutions and the Manifestation of Bias: The Effect of the Personal Vote on the Representation of Women." Politics Eamp; Gender $9(01): 76-92$.

Volkens, Andrea. 2007. "Strengths and weaknesses of approaches to measuring policy positions of parties." Electoral Studies 26(1):108-120.

Volkens, Andrea, Judith Bara, Ian Budge, Michael D McDonald and Hans-Dieter Klingemann. 2013. Mapping policy preferences from texts: statistical solutions for manifesto analysts. Vol. 3 Oxford University Press.

Von Beyme, Klaus. 1985. Political parties in Western democracies. Gower Publishing Company, Limited.

Wiesehomeier, Nina and Kenneth Benoit. 2009. "Presidents, parties, and policy competition." The Journal of Politics 71(04):1435-1447.

Zittel, Thomas and Thomas Gschwend. 2008. "Individualised constituency campaigns in mixed-member electoral systems: Candidates in the 2005 German elections." West European Politics 31(5):978-1003. 


\title{
A Appendix
}

\section{A.1 Appendix: Questions used from DALP survey}

Party nomination control: The DALP survey question producing this variable is as follows:

\begin{abstract}
More generally, the power to select candidates in national legislative elections is always divided between local/municipal party actors, regional/state-level party organizations, and national party leaders. Often one particular level of party organization dominates the selection process, while in other places candidate selection is the outcome of bargaining between the different levels of party organization. Which of the following four options best describes the following parties' balance of power in selecting candidates for national legislative elections? [1] National party leaders control the process of candidate selections , [2] Regional/state-level party organizations control the process of candidate selections, [3] Local/municipal actors control the process of candidate selections, [4] Selection is the outcome of bargaining between different levels
\end{abstract}

This variable is originally constructed as ordinal using a continuous average across experts. We convert this variable into a dichotomy based on the original expert-level data. To do this, we simply assign 1 to parties where a majority for experts indicated a national party nomination system and 0 to parties in which most experts indicated a mostly subnational nomination process. In several cases the experts were evenly split between these and to these we assigned the 0 category. We also examined the results in which these cases were assigned the category of 0 and find results similar to those presented in the table. Our results in table 3 are also similar using the original ordinal variable directly from the individual-level DALP data set. However, we believe that the rank ordering of category 
4 cannot be easily averaged with categories 1-3.

Party Emphasis on Policy Positions: The DALP question producing this variable is as follows:

Please indicate the extent to which parties seek to mobilize electoral support by emphasizing the attractiveness of the partys positions on policy issues. [1] Not at all, [2] To a small extent [3] To a moderate extent [4] To a great extent These results are averaged across the experts to produce a continuous variable released as part of the individual-level DALP data set. 
Figure 5: Scaled Coordinates by Country (CCS)

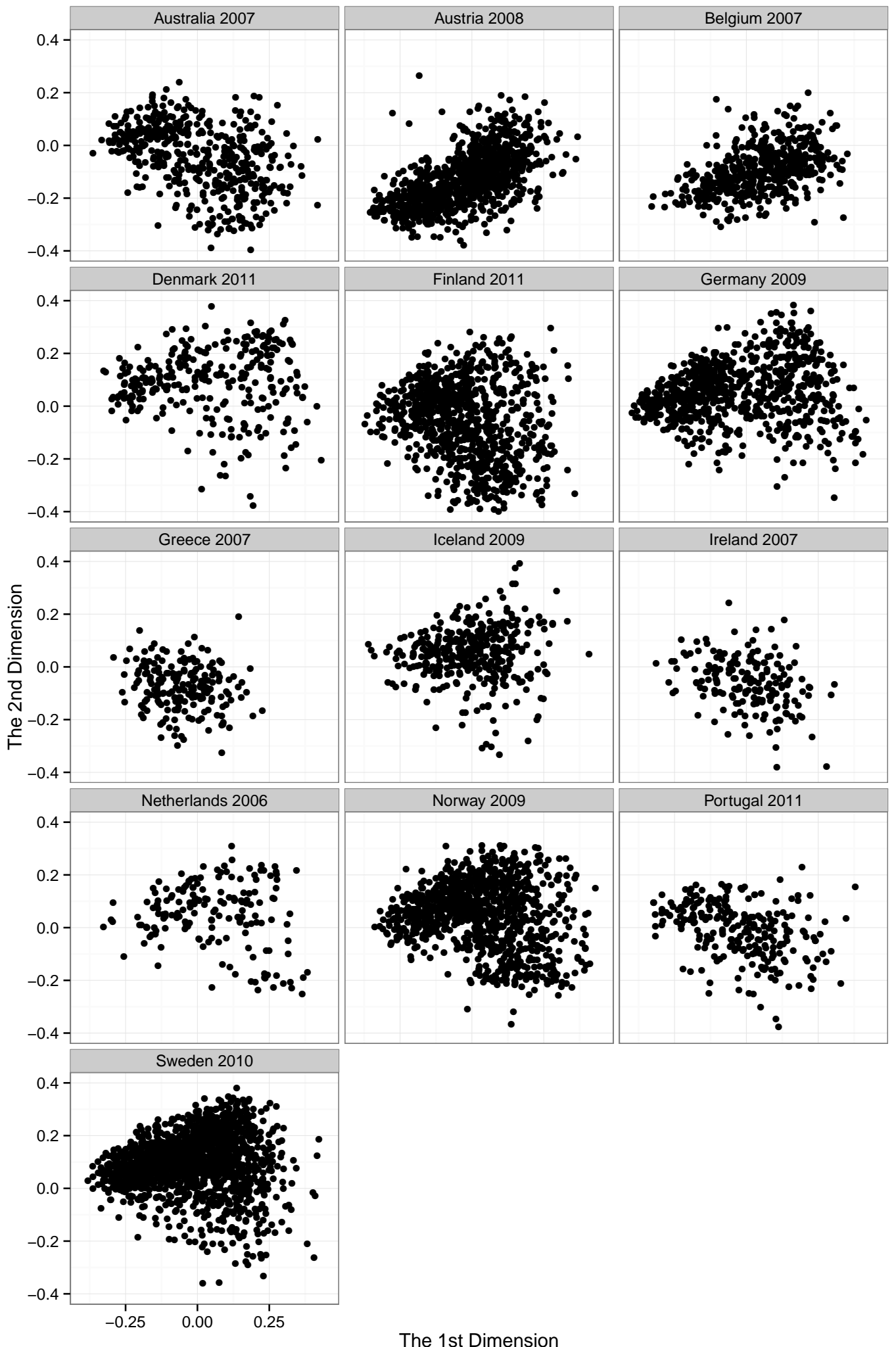

The 1st Dimension 


\section{A.2 Estimated response rate bias by party: comparisons with party family and ideology}

As noted above, the response rate can pose a potential problem for generating representa-

tive statistics from the CCS questions. Although we find promising predictability among the first dimension coordinates in terms of overall left-right placements for parties, here we evaluate more closely whether the response rates may have distorted the positions of individual parties. To do this, we calculate an estimated response rate per party by looking at the difference between the proportion of responses and the most proximate vote share for that party. We then subtract this quantity from the vote chair in order to determine the gap between the expected and actual proportion of responses. If a party appears to have an unusual response rate on this metric, it may also be distorted in terms of how the party overall is positioned. In the figures 6 and 7 below we plot this metric against, first, the party family and, second, the quartiles of the ideological spectrum, based on expert judgements from the CHES data used above. First, we note that 76 percent of parties in our data have gaps between actual and expected responses below 10 percent. In general, this gap is relatively small and has no apparent relationship with any party type. Our interpretation is that no party type stands out as being particularly unusual with regard to response rates. 
Figure 6: Response rate-vote share gap, by party family

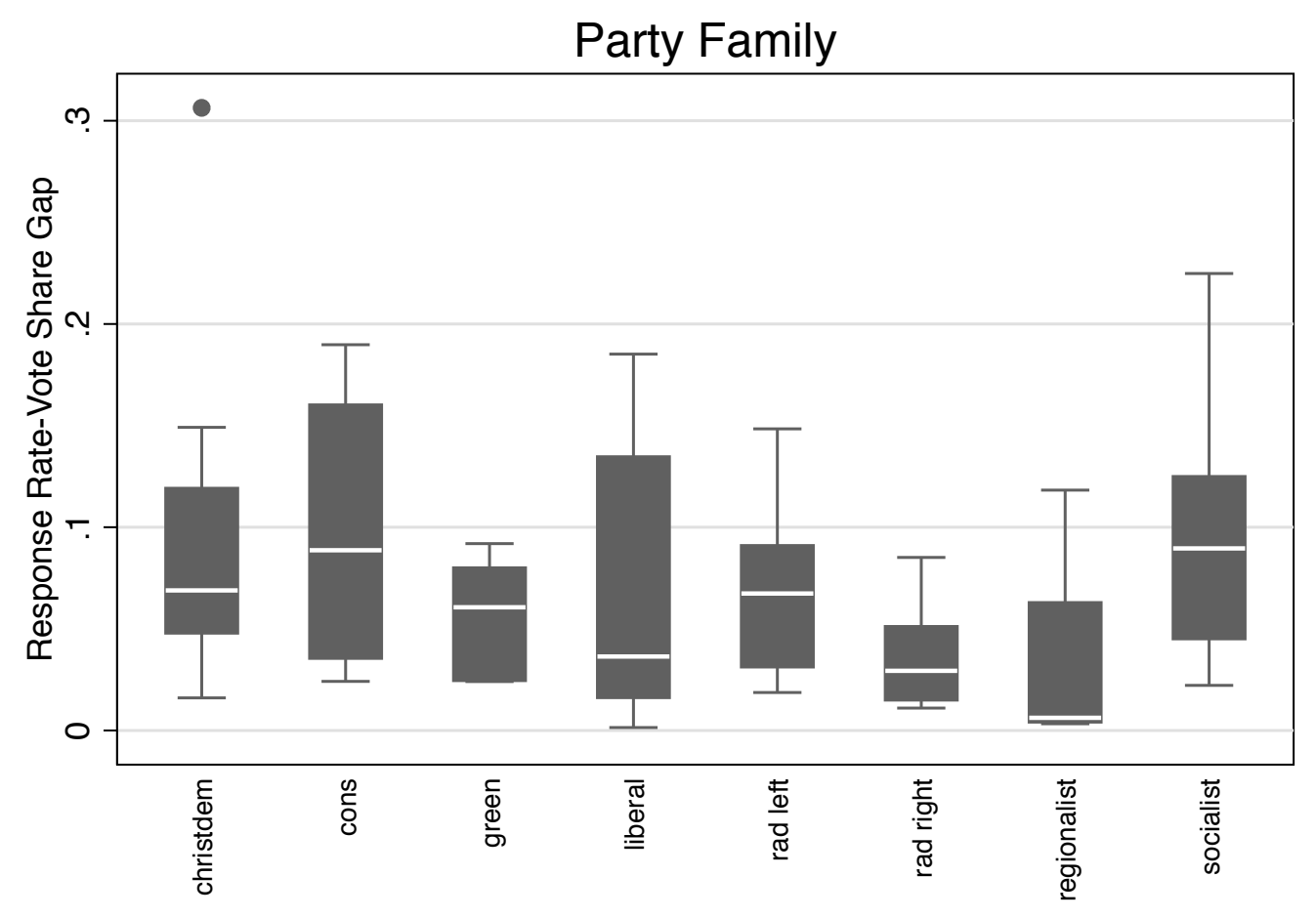

Figure 7: Response rate-vote share gap, by ideology quartile

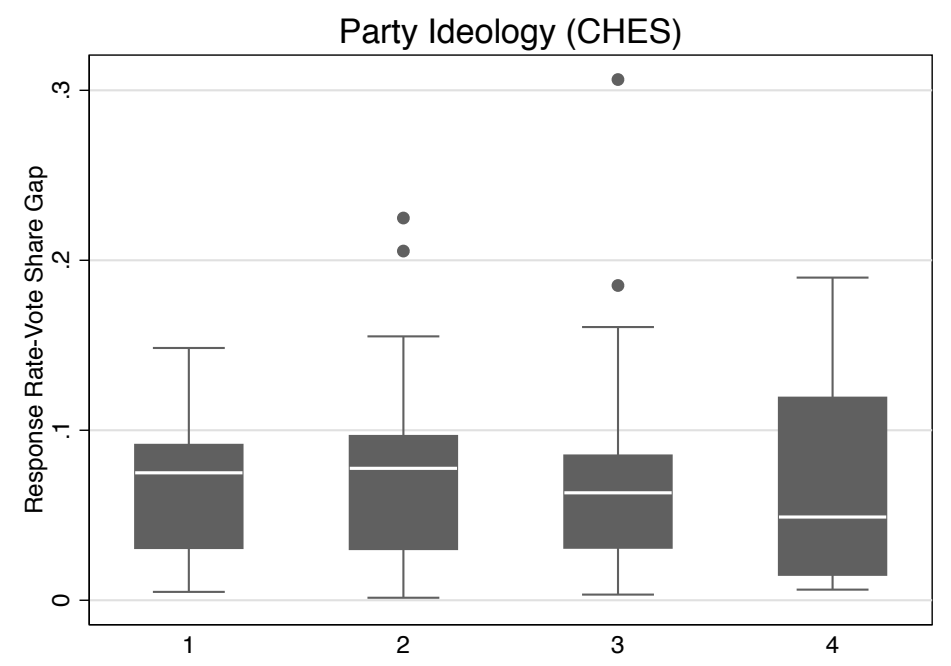




\section{A.3 Appendix: Additional tables on substantive interpretation of the estimates}

Table 4: Correlations between Estimated Elite Ideology and CHES policy questions

\begin{tabular}{lrr}
\hline & 1st Dim. Ideal Points & 2nd Dim. Ideal Points \\
\hline LR General & 0.8857 & 0.0516 \\
LR Econ & 0.8361 & 0.1933 \\
GAL-TAN & 0.7236 & -0.2614 \\
Spend v. Tax & 0.8347 & 0.1550 \\
Deregulation & 0.7929 & 0.2817 \\
Redistribution & 0.8215 & 0.2548 \\
Civ-lib/Law-Order & 0.8195 & -0.0938 \\
Social/Lifestyle & 0.6386 & -0.3715 \\
Religious Principle & 0.5701 & -0.3459 \\
Immigration & 0.7651 & -0.1540 \\
Multiculturalism & 0.7860 & -0.2581 \\
Urban-Rural & 0.4040 & -0.2165 \\
Environment & 0.7861 & -0.0552 \\
Regions & 0.1393 & 0.0952 \\
International Security & -0.6983 & -0.3735 \\
Ethnic Minorities & 0.7895 & -0.1841 \\
\hline
\end{tabular}


Table 5: Correlation of Scaled Estimates with Individual Policy Questions in CCS

\begin{tabular}{lrr}
\hline CCS Question Code & 1st Dim Ideal Points & 2nd Dimension Ideal Points \\
\hline C2a & -0.64 & 0.26 \\
C2b & -0.50 & -0.11 \\
C2c & 0.55 & 0.04 \\
C2d & -0.42 & 0.76 \\
C2e & 0.52 & 0.15 \\
C2f & -0.58 & 0.31 \\
C2g & 0.48 & 0.19 \\
C2h & 0.74 & 0.29 \\
C2i & 0.27 & 0.30 \\
C2j & 0.44 & -0.35 \\
C2k & 0.44 & -0.40 \\
C2l & -0.71 & -0.20 \\
C2m & 0.42 & -0.25 \\
C2n & -0.22 & -0.53 \\
\hline
\end{tabular}

